\title{
New records on edible mushrooms collected from Guba district
}

Aytaj A. Alimammadova ${ }^{1}$

Dilzara N. Aghayeva

Institute of Botany, Azerbaijan National Academy of Sciences, Badamdar 40, Baku, AZ1004, Azerbaijan

Abstract: The study presents first information on edible mushrooms of Guba district. Specimens were collected in 2017-19 in forest ecosystem. As a result of the study, 17 species (Amanita rubescens, Boletus edulis, B. reticulatus, Cerioporus squamosus, Clitocybe odora, Clitopilus prunulus, Coprinellus micaceus, Hortiboletus rubellus, Laetiporus sulphureus, Leccinellum pseudoscabrum, Legaliana badia, Lycoperdon perlatum, Macrolepiota mastoidea, M. procera, Russula risigallina, $R$. turci, Xerocomellus chrysenteron) of edible mushrooms belonging to 14 genera were identified. Legaliana badia is a new record for Azerbaijan mycobiota. All other mushroom species are new records for the study area. GPS coordinates and ecological groups of mushrooms were identified.

Keywords: Ascomycetes, Basidiomycetes, diversity, ecological groups, food quality, species

\section{INTRODUCTION}

Mushrooms have been consumed since the earliest human history. They were considered as providers of strength and named as "elixir of life" in ancient times [Valverde et al., 2015]. Since the 5th century, some medicinal mushrooms such as Ganoderma lucidum (Curtis) P. Karst and Polyporus umbellatus (Pers.) Fr. were noted by the alchemist Tao Hongjing [Stamets, Zwickey, 2014]. Since that time interest to mushrooms is increasingly growing [Kumar et al., 2021; Qwarse et al., 2021; Roupas et al., 2012]. Currently edible mushrooms are used in more than 80 countries of the world, especially for their unique flavour and culinary wonders [Barros et al., 2007; Novakovic et al., 2019].

Also, medicinal importance of some mushrooms has been comprehensively studied in recent years and is already used in the treatment of a number of diseases, such as cancer, diabet and neurodegenerative diseases [Wasser, 2016]. However, no special distinction is made between medicinal and edible mushrooms because many common edible species have therapeutic properties and some of those used for medicinal purposes are also edible, such as Cantharellus cibarius, Cerioporus squamosus, Laetiporus sulphureus and etc [Elkhateeb et al., 2020; Khatua et al., 2017; Novakovic et al., 2019].

Mushrooms play an important ecological role in the world [Hyde et al., 2019; Olah et al., 2020; Teke et al., 2019]. Many of the leading species live symbiotically with plant and some of them have a mycorrhizal association. Saprobic wild edible mushrooms are important in nutrient recycling [Boa, 2004; McGonigle, 2011].

Since 1950s, the mushroom diversity in the Guba district has been studied by local mycologists. Few herbarium specimens have been collected and are kept at the mycological herbaium of the Institute of Botany of ANAS (BAK). However, there have been no specific studies of macromycetes in this district. Taking all this into account, the aim of this study is to discover macromycete diversity of the research area and determine wild edible mushrooms growing in the territory.

\section{MATERIAL AND METHODS}

Distribution of study area. The relief of the district is mostly mountainous with predominance of broadleaved mountain forests consisting of by Carpinus orientalis Mill., Fagus orientalis Lipsky, Quercus robur L. trees. The climate of the district is dry in summer, moderately hot in the foothills, but cold and humid in winter [Aghayeva et al., 2021].

Field studies. The research was carried out in 2017-19 on mushrooms collected from Armaki, Ispik, Gultepe, Gechresh, Gryzdahna, Kupchal, Kusnetgazma, Uchgun, II Nugadi villages of Guba district in spring, summer and autumn (May, July, October). The initial morphological features for each mushroom specimens (size, color, shape, surface texture, structure of hymenium and reticulum, whether or not volva and annulus, mushroom odour and taste, color change when cut, etc.) were recorded, photos were taken at the point of collection. 
Microscopic studies. All newly collected samples were carefully dried and herbarium specimens were deposited in the BAK. Observation of the samples is based on classical approaches using distilled water, sometimes Congo Red solution. Main diagnostic features were examinated under the microscope (Axio Imager Vert. A1 Carl Zeiss, Germany). For each specimen, 30 spores were measured and their average mean value was calculated. Photos of microscopic structures were obtained using the Axiocam (Zeiss, 105 color).

Identification of mushrooms were carried out according to available literature: [Arora, 1986; Breitenbach, Kränzlin, 1984; Dermek, 1979; Erdem, 2018; Grunert, Grunert, 2002; Mustafabayli et al., 2021; Sadiqov, 2001, 2007; Van Vooren, 2020].

Nomenclature and taxonomy correspond to Index Fungorum [http://indexfungorum.org/] and MycoBank [http://www.mycobank.org/] databases.

\section{RESULTS AND DISCUSSION}

As a result of the sample analysis collected from the forest and meadows of the study area, 17 species of edible mushrooms belonging to five orders (Agaricales, Boletales, Pezizales, Polyporales, Russulales), 11 families (Agaricaceae, Amanitaceae, Boletaceae, Entolomataceae, Fomitopsidaceae, Lycoperdaceae, Pezizaceae, Polyporaceae, Psathyrellaceae, Russulaceae, Tricholomataceae) and 14 genera were identified. Legaliana badia represents a new record for Azerbaijan and all other species are new records for the study area.

These mushrooms differ according to their ecological groups. Thus, two of them are xylotropic, six of them - saprotrophic and nine of them - mycorrhizal. Information on the recorded species is provided below.

\section{Ascomycota}

Pezizales

Pezizaceae Dumort

Legaliana badia (Pers.) Van Vooren (Fig. 1)

Ispik village, $\mathrm{N} 41^{\circ} 18^{\prime} 32^{\prime \prime} \mathrm{E} 0$ 48 $25^{\prime} 05^{\prime \prime}, 25$ May 2019 , (BAK1720).

Macroscopic features: fruiting body about $6 \mathrm{~cm}$, cupshaped, irregular undulating, stalkless. Hymenium or inner surface (fertile) is smooth, dark olive-brown color, outer surface (infertile) dust reddish-brown, finely scurfy-furfuraceous. Flesh is fragile, thin, reddishbrown.

Microscopic features: spores hyaline, ellipsoidial, 17-19 $\times 8-10.2 \mu \mathrm{m}$ in size, coarsely warty, colorless, with one
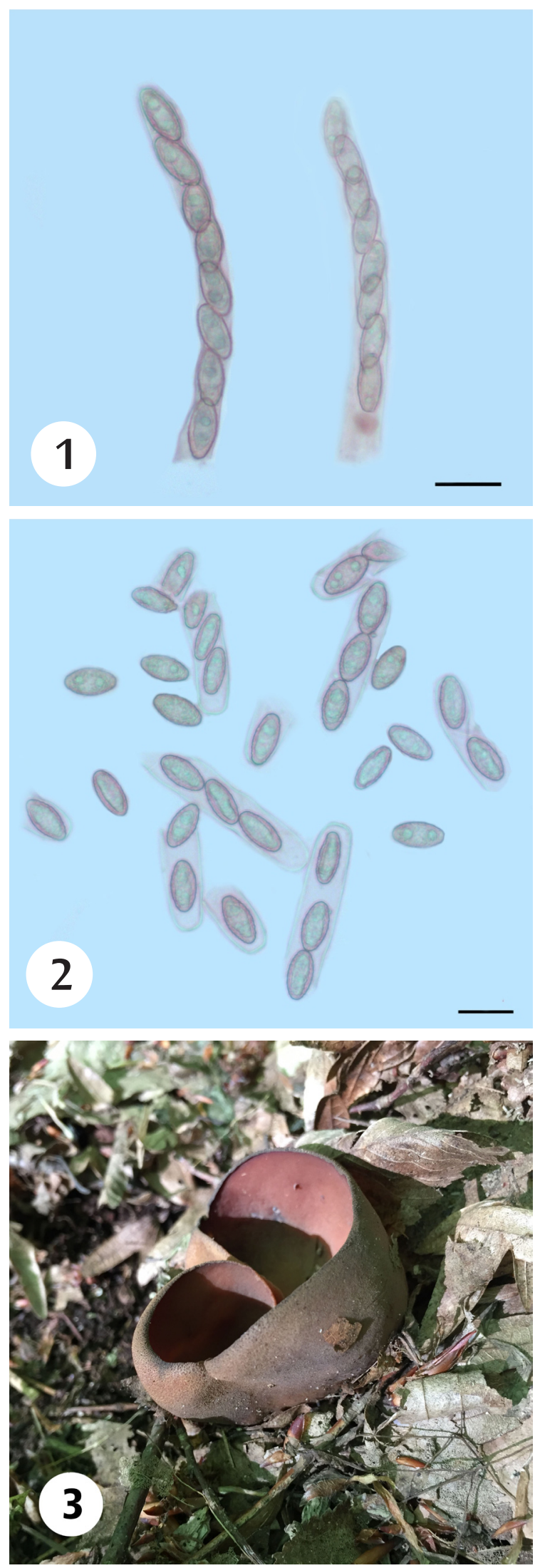

Figure 1. Legaliana badia - a new record for Azerbaijan: 1 - ascospores in asci; 2 - ascospores; 3 - fruit body. 


\section{PLANT \& FUNGAL RESEARCH}

or two oil drops. Spore print is white. Asci eight-spored, $300 \times 15 \mu \mathrm{m}$. Growing gregariosusly, in deciduous forests, saprotrophic and occurs on compacted heavy solis. Edible, but odor and taste are not distinctive [Dermek, 1979].

Note: The species was mentioned for the Caucasus without exact distinction place [Barseghyan, Wasser, 2011].

\section{Basidiomycota}

Agaricales

Agaricaceae Chevall

Macrolepiota mastoidea (Fr.) Singer (Fig. 2 A)

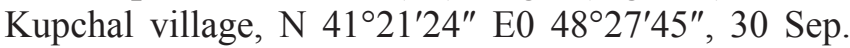
2018, (BAK1710), saprotrophic, found singly.

Note: M. mastoidea is edible mushroom, but only the cap is valuable for food and can be eaten raw. The stems are wooden [Arora, 1986].

Macrolepiota procera (Scop.) Singer (Fig. 2 B)

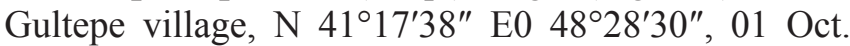
2018, (BAK1708), saprotrophic, found singly in chestnut plantation.

Note: $M$. procera is common edible mushroom. Only the cap of the adult individuals is edible, stems are wooden [Grunert, Grunert, 2002].

Amanitaceae R. Heim ex Pouzar

Amanita rubescens Pers. (Fig. 2 C)

Ispik village, $\mathrm{N} 41^{\circ} 18^{\prime} 32^{\prime \prime} \mathrm{E} 048^{\circ} 25^{\prime} 05^{\prime \prime}, 15$ July 2019 , (BAK1704), mycorrhizal, found in groups, under the $C$. orientalis.

Note: A. rubescens tastes good, but after a long period of rains it tastes earthy. Edible if thoroughly cooked, otherwise it is indigestible and can cause serious illness. In raw form this mushroom is poisonous due to compound hemolysin. It is highly esteemed in Europe and edible in our locality [Arora, 1986; Sadiqov, 2007].

Entolomataceae Kotl. \& Pouzar

Clitopilus prunulus (Scop.) P. Kumm. (Fig. 2 D)

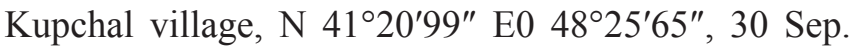
2018, (BAK1721), saprotrophic, found in groups, under the $F$. orientalis.

Note: C. prunulus is edible but not highly rated mushroom in the world. Mushroom is strongly mealy. They are morphologically similiar to poisonus Clitocybe dealbata or C. rivulosa although, but these generally grow in rings in grassland [Grunert, Grunert, 2002; O'
Reilly, 2016].

Lycoperdaceae F. Berchtold \& J.S. Presl

Lycoperdon perlatum Pers. (Fig. $2 \mathrm{E}$ )

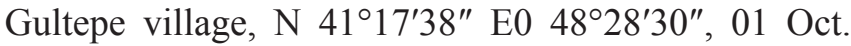
2018, (BAK1722), saprotrophic, found in groups.

Note: L. perlatum is edible and delicious at young age when it firm and white, but yellowish specimens are not edible [Grunert, Grunert, 2002].

Psathyrellaceae Vilgalys, Moncalvo \& Redhead

Coprinellus micaceus (Bull.) Vilgalys, Hopple \& Jacq. Johnson (Fig. 2 F)

Uchgun village, N 41 $19^{\prime} 47^{\prime \prime}$ E0 48 22'57", 02 Oct. 2018, (BAK1707), saprotrophic, on meadow, often occurs in large numbers.

Note: C. micaceus is edible, but thin-fleshed and watery with pleasant flavour. It is edible within 1 to 3 hours. It is rich in potassium. Coprinus species produce the compound coprine. In combination with the alcohol, it causes "Coprinus syndrome" [Michelot, 1992].

Tricholomataceae R. Heim ex Pouzar

Clitocybe odora (Bull.) P. Kumm. (Fig. 2 G)

Ispik village, $\mathrm{N} 41^{\circ} 18^{\prime} 32^{\prime \prime}$ E0 48 25'05", 04 Oct. 2019, (BAK1730), mycorrhizal, found in groups, under the $F$. orientalis.

Note: $C$. odora is edible, most often used as food additive to flavor [Grunert, Grunert, 2002].

Boletales

Boletaceae Chevall.

Boletus edulis Bull. (Fig. $2 \mathrm{H}$ )

Ispik village, N 4118'32" E0 48 25'05", 15 July 2019, (BAK1729), mycorrhizal, found singly, under the $C$. orientalis.

Note: B. edulis is a well-known edible mushroom. According to D. Arora odor and taste of dried B. edulis are marvelous-nutty, earthy and meaty [1986].

B. reticulatus Schaeff. (Fig. 2 I)

Ispik village, N 4118'32" E0 48 25'05", 15 July 2019, (BAK1723), mycorrhizal, found singly, under the $C$. orientalis.

Note: The texture and taste are almost identical to $B$. edulis [Arora, 1986].

Leccinellum pseudoscabrum (Kallenb.) Mikšík

(Fig. $2 \mathrm{~J}$ )

Ispik village, N 4118'32" E0 48 25'05", 15 July 2019, (BAK1728), mycorrhizal, found in groups. 

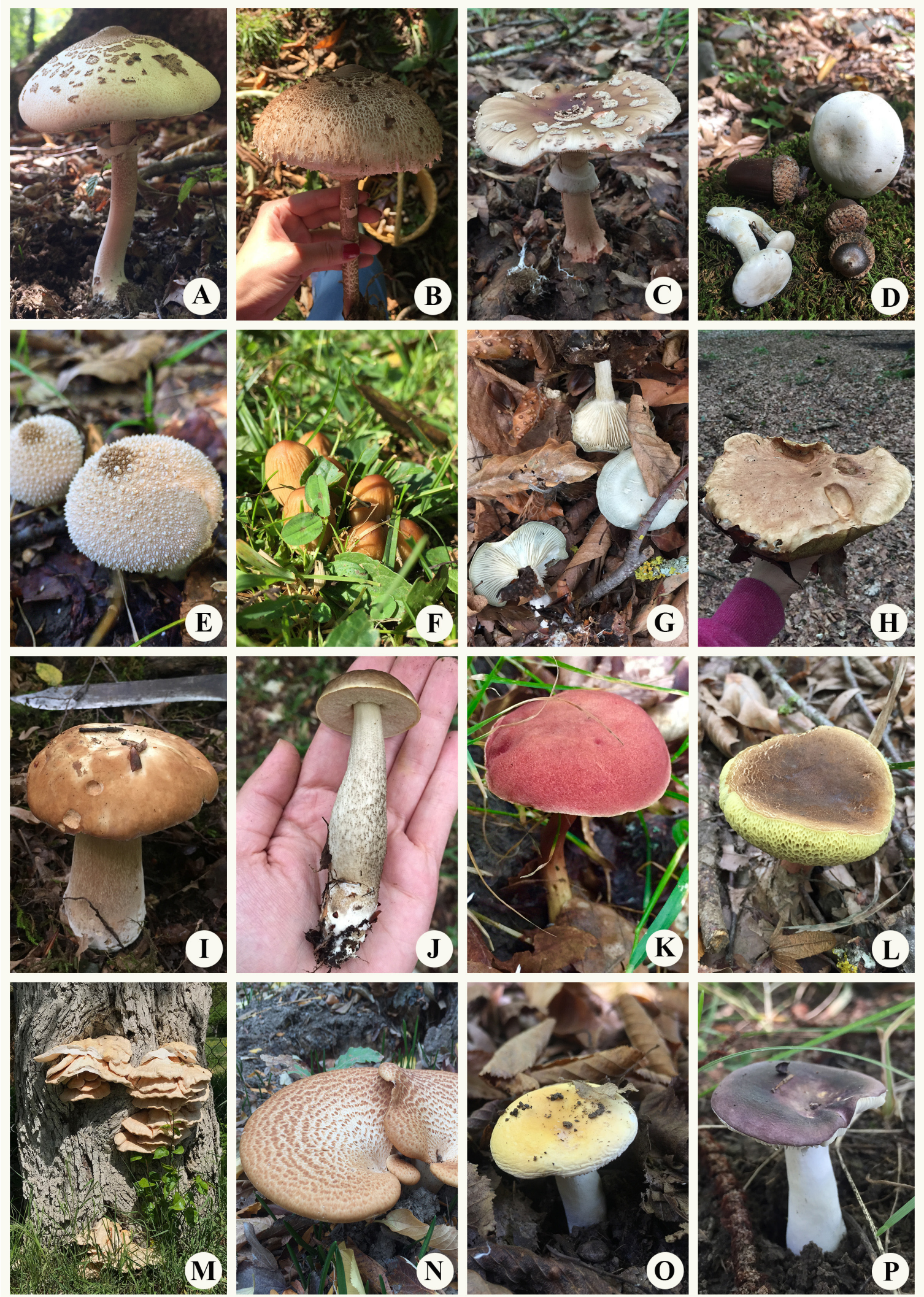

Figure 2. New records for Guba district: A. Macrolepiota mastoidea; B. M. procera; C. Amanita rubescens; D. Clitopilus prunulus; E. Lycoperdon perlatum; F. Coprinellus micaceus; G. Clitocybe odora; H. Boletus edulis; I. B. reticulatus; J. Leccinellum pseudoscabrum; K. Hortiboletus rubellus; L. Xerocomellus chrysenteron; M. Laetiporus sulphureus; N. Cerioporus squamosus; O. Russula risigallina; P. R. turci. 


\section{PLANT \& FUNGAL RESEARCH}

Note: L. pseudoscabrum is moderately edible. Their odor is pleasant, but not distinctive [Arora, 1986; Mustafabayli, 2020].

Hortiboletus rubellus (Krombh.) Simonini, Vizzini \& Gelardi (Fig. 2 K)

Ispik village, N 4118'32" E0 48 25'05", 15 July 2019, (BAK1705), mycorrhizal, found singly.

Note: Mushroom has soapy flavour and no significant taste [Watling, Hills, 2005].

Xerocomellus chrysenteron (Bull.) Šutara (Fig. 2 L)

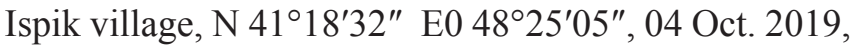
(BAK1726), mycorrhizal, found singly.

Note: $X$. chrysenteron is generally considered edible if it is cooked thoroughly [Hills, 2008].

Polyporales

Fomitopsidaceae Jülich

Laetiporus sulphureus (Bull.) Murrill (Fig. $2 \mathrm{M}$ )

Kusnetgazma village, N 4116'32" E0 48 20'15", 19 May 2019, (BAK1731), xylotrophic, found in groups, on the $C$. orientalis.

Note: L. sulphureus, with its sulfur yellow color also known as the "Chicken of the woods". The mushroom is edible [Katarzyna et al., 2018; Khatua et al., 2017].

Polyporaceae Corda

Cerioporus squamosus (Huds.) Quél. (Fig. $2 \mathrm{~N}$ )

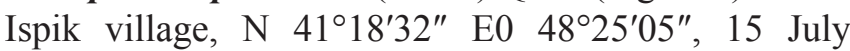
2019, (BAK1727), xylotrophic, found singly, on the $C$. orientalis.

Note: C. squamosus is edible. Young fruiting bodies are soft. This mushroom has nutritional value as they are rich in proteins and considered vital sources of many vitamins - B1, B2, B12, C, D and E [Elkhateeb et al., 2020].

Russulales

Russulaceae Lotsy, Truffe

Russula risigallina (Batsch) Sacc. (Fig. 2 O)

Kupchal village, N 4121'24" E0 48 27'45", 30 Sep. 2018, (BAK1724), mycorrhizal, around the tree Quercus $r$. area, found singly.

Note: $R$. risigallina is edible. Taste is mild, odor is fruity when matured. Edible only in the cooked form [Sadiqov, 2007].

Russula turci Bres. (Fig. 2 P)

Gultepe village, N 4117'38" E0 48²8'30", 01 Oct.
2018, (BAK1725), mycorrhizal, found singly, under the Castanea sp.

Note: $R$. turci is a common edible with a pleasant, nonbitter taste [Mustafabayli, Aghayeva, 2019].

\section{CONCLUSION}

Mushrooms were not favourite food for people living in Azerbaijan until last few decades [Mustafabayli, 2020]. Most of local population are not familiar with edible mushrooms and avoid them due to a number of cases of poisoning. In this article we report about 17 species that are well distributed in the Guba district.

It is well-known today edible mushrooms are valuable, not only due to their unique flavor and texture, but because of their important nutritional and medicinal properties. Mushrooms are rich in minerals, proteins, dietary fiber, essential oils and vitamins. In addition, they are low in calories, fat and cholesterol [Boonsong et al., 2016; Friedman, 2016]. Also species such as $M$. procera and B. edulis have been suggested to have strong antioxidant, antimicrobial, and anti-cancer potentials. In the future, we plan to study the biological characteristics of edible and medicinal fungi found in the study territory [Kosanić et al., 2016, 2017].

\section{REFERENCES}

Aghayeva P., Cozzolino S., Cafasso D., Ali-zade V., Fineschi S., Aghayeva D. (2021) DNA barcoding of native Caucasus herbal plants: potentials and limitations in complex groups and implications for phylogeographic patterns. Biodivers. Data J, 9: e61333. https://doi.org/10.3897/BDJ.9.e61333

Arora D. (1986) Mushrooms demystified. A comprehensive guide to the fleshy fungi. $2^{\text {nd }}$ edition. Berkeley: Ten Speed Press, 959 p.

Barros L., Baptista P., Correia M.D., Casal S., Oliveira B., Ferreira I.C.F.R. (2007) Fatty acid and sugar compositions, and nutritional value of five wild edible mushrooms from Northeast Portugal. Food Chem., 105: 140-145.

Barseghyan G.S., Wasser S.P. (2011) The genus Peziza Dill. ex Fr. (Pezizales, Ascomycota) in Israel. Ascomycete.org, 2(4): 39-50.

Boonsong S., Klaypradit W., Wilaipun P. (2016) Antioxidant activities of extracts from five edible mushrooms using different extractants. ANRES, 50: 89-97.

Breitenbach J., Kränzlin F. (1984) Fungi of Switzerland. Vol 1 - Ascomycetes, $311 \mathrm{pp}$.

Dermek A. (1979) Atlas of our books. Review, 439 p. 
[Dermek A. (1979) Atlas našich hŭb. Obzor, 439 p.] Elkhateeb W.A., Daba G.M., Elnahas M.O., Thomas P.W., Mahmoud Emam (2020) Metabolic profile and skin-related bioactivities of Cerioporus squamosus hydromethanolic extract. Biodiversitas, 21(10): 4732-4740.

Erdem Y. (2018) Handbook of Mushroom Hunters. Samsun, Turkey: Bafra, 332 pp. [Erdem Y. (2018) Mantar Avcısının El Kitabı. Samsun, Türkiye: Bafra, 332 s.]

Eric Boa (2004) Wild edible fungi a global overview of their use and importance to people. Non-food forest products FAO, Rome, $147 \mathrm{pp}$.

Friedman M. (2016) Mushroom polysaccharides: chemistry and antiobesity, antidiabetes, anticancer, and antibiotic properties in cells, rodents, and humans. Foods, 5(4): 80.

Grunert G., Grunert B. (2002) Mushrooms. Moscow: AST-Astrel, 288 pp. [Грюнерт Г., Грюнерт Р. (2002) Грибы. Москва: АСТ-Артель, 288 с.]

Hills A.E. (2008) The genus Xerocomus. A personal view, with a key to the British species. Field Mycology, 9(3): 77-96.

Hyde K.D., Xu J., Rapior S., Jeewon R., Lumyong S., Niego A.G.T., Abeywickrama P.D., Aluthmuhandiram J.V.S., Brahamanage R.S., Brooks S., Chaiyasen A., Chethana K.W.T., Chomnunti P., Chepkirui C., Chuankid B., De Silva N.I., Doilom M., Faulds C., Gentekaki E., Gopalan V., Kakumyan P., Harishchandra D., Hemachandran H., Hongsanan S., Karunarathna A., Karunarathna S.C., Khan S., Kumla S., Jayawardena R.S., Liu J.-K., Liu N., Luangharn T., Macabeo A.P.G., Marasinghe D.S., Meeks D., Mortimer P.E., Mueller P., Nadir S., Nataraja K.N., Nontachaiyapoom S., O'Brien M., Penkhrue W., Phukhamsakda C., Ramanan U.S., Rathnayaka A.R., Sadaba R.B., Sandargo B., Samarakoon B.C., Tennakoon D.S., Siva R., Sriprom W., Suryanarayanan T.S., Sujarit K., Suwannarach N., Suwunwong T., Thongbai B., Thongklang N., Wei D., Wijesinghe S.N., Winiski J., Yan J., Yasanthika E., Stadler M. (2019) The amazing potential of fungi: 50 ways we can exploit fungi industrially. Fungal Divers., 97:1-136. https:// doi.org/10.1007/s13225-019-00430-9

Index Fungorum. http://indexfungorum.org

Keys to Agaricum mushrooms of Transcaucasia (1985)

Ed. I.G. Nakhutsrishvili. Tbilisi: Metseniereba, 264 pp. [Определитель Агарикальных грибов Закавказья. Ред: И.Г. Нахуцришвили. Тбилиси:
Мецниереба, 264 с.]

Khatua S., Ghosh S., Acharya K. (2017) Laetiporus sulphureus (Bull.: Fr.) Murr. as Food as Medicine. Pharmacog J., 9(6): 1-15.

DOI : $10.5530 / \mathrm{pj} .2017 .6 \mathrm{~s} .151$

Kosanić M., Ranković B., Rančić Aş, Stanojković T. (2016) Evaluation of metal concentration and antioxidant, antimicrobial, and anticancer potentials of two edible mushrooms Lactarius deliciosus and Macrolepiota procera. J Food Drug Anal. 24: 47784.

Kosanić M., Ranković B., Rančić A., Stanojković T. (2017) Evaluation of metal contents and bioactivity of two edible mushrooms Agaricus campestris and Boletus edulis. EJFA., 29: 98-103.

Kumar H., Bhardwaj K., Sharma R., Nepovimova E., Cruz-Martins N., Dhanjal D.S., Singh R., Chopra C., Verma R., Abd-Elsalam K.A., Tapwal A., Musilek K., Kumar D., Kuča K. [2021] Potential usage of edible mushrooms and their residues to retrieve valuable supplies for industrial applications. J. Fungi, 7: 427. https://doi.org/10.3390/jof7060427

McGonigle T.P. (2011) The significance of grazing on fungi in nutrient cycling. Can J Bot, 73(1): 13701376. DOI: 10.1139/b95-399

Mustafabayli E.H., Aghayeva D.N. (2019) New records of mushrooms for the mycobiota of Azerbaijan. Ukr Bot J, 76(4): 356-361.

Mustafabayli E.H. (2020) Edible and poisonous fungi of Azerbaijan. Plant \& Fungal Research, 3(1): 5460. doi.org/10.29228/plantfungalres.69

Mustafabayli E.H., Prydiuk M.P., Aghayeva D.N. (2021) New for Azerbaijan records of agaricoid fungi collected in Shaki District. Ukr Bot J, 78(3): 214-220. https://doi.org/10/15407/ukrbotj78.03.214

MycoBank. http://www.mycobank.org

Novakovic S., Djekic I., Klaus A., Vunduk J., Djordjevic V., Tomovič V., Šojič B., KocičTanackov S., Lorenzo J.M., Barba F.J., Tomasevic I. (2019) The effect of Cantharellus cibarius addition on quality characteristics of Frankfurter during refrigerated storage. Foods, 8: 635-646. doi:10.3390/ foods 8120635

O' Reilly P. (2016) Fascinated by Fungi, 450 p.

Olah B., Kunca V., Gallay I. (2020) Assessing the potential of forest stands for ectomycorrhizal mushrooms as a subsistence ecosystem service for socially disadvantaged people: a case study from Central Slovakia. Forests, 11(3): 282-295. https:// doi.org/10.3390/f11030282 
Qwarse M., Moshi M., Mihale M.J., Marealle AI., Sempombe J., Mugoyela V. (2021) Knowledge on utilization of wild mushrooms by the local communities in the Selous-Niassa Corridor in Ruvuma Region, Tanzania. J. Yeast Fungal Res., 12(1): 8-19 DOI: 10.5897/JYFR2020.0203

Roupas P., Keogh J., Noakes M., Margetts C., Taylor P. (2012) The role of edible mushrooms in health: Evaluation of the evidence. J. Funct. Foods, 4: 687709.

Sadigov A.S. (2001) Agarical xylotrophic fungi of Azerbaijan. Proceedings of Azerbaijan National Academy of Sciences, (4-6): 15-19. [Sadiqov A.S. (2001) Azərbaycanın aqarikal ksilotrof göbələkləri. Azarbaycan Milli Elmlar Akademiyasının xabarlari, (4-6): 15-19]

Sadigov A. (2007) Edible and poisonous mushrooms of Azerbaijan. Baku: Elm, 109 pp. [Sadıqov A.S. (2007) Azərbaycanın yeməli və zəhərli göbələkləri. Bak1: Elm, 109 s.]

Stamets P., Zwickey H. (2014) Medicinal mushrooms: ancient remedies meet modern science. Integr Med (Encinitas)., 13(1): 46-47.

Sułkowska-Ziaja K., Muszyńska B., Gawalska A., Sałaciak K. (2018) Laetiporus sulphureus chemical composition and medicinal value. Acta Sci. Pol. Hortorum Cultus, 17(1): 89-98. DOI: 10.24326/ asphc.2018.1.8

Teke A.N., Kinge T.R., Bechem E.E.T., Ndam L.M., Mih A.M. (2019) Mushroom species richness, distribution and substrate specificity in the KilumIjim forest reserve of Cameroon. J. Appl. Biosci., 133: $13592-13617$.

Van Vooren N. (2020) Reinstatement of old taxa and publication of new genera for naming some lineages of the Pezizaceae (Ascomycota). Ascomycete.org, 12(4): 179-192. DOI:10.25664/ART-0305

Valverde M.A., Hernández-Pérez T., ParedesLópez O. (2015) Edible mushrooms: Improving human health and promoting quality life. Int. J. Microbiol., Article ID 376387, 14 p. http://dx.doi. org/10.1155/2015/376387

Wasser S.P. (1973) Agarical mushrooms of the Primorsky territory. L .: Nauka, 331 pp. [Baccep С.П. (1973) Агариковые шляпочные грибы Приморского края. Л.: Наука, 331 с.]

Wasser S.P. (2014) Medicinal mushroom science: current perspectives, advances, evidences, and challenges. Biomed J., 37: 345-356.
Wasser S.P. (2016) Macromycetes: medicinal properties and biological peculiarities. T.2./Ed. by Prof. J.Gabriel. Kyiv: Nash format, 261 p. [Baccep С.П. (2016) Макромицеты: лекарственные свойства и биологические особенности. Т.2. Под ред. проф. И. Габриэля. Киев: Наш формат, 261 с.]

Watling R., Hills A.E. (2005) Boletes and their allies. British Fungus Flora. Agarics and boleti. Royal Botanic Garden, Edinburgh, Vol. 1.

Zhang M.Z., Li G.J., Dai R.C., Xi Y.L., Wei S.L., Zhao R.L. (2017) The edible wide mushrooms of Agaricus section Bivelares from Western China. Mycosphere, 8(10): 1640-1652. Doi 10.5943/mycosphere/8/10/4

\section{Quba rayonundan toplanılmış yeməli göbələklərə dair yeni qeydlor}

\section{Aytac A. Oliməmmədova \\ Dilzarə N. A ğayeva}

AMEA Botanika İnstitutu, Badamdar şossesi 40, Bakl, AZ1004, Azərbaycan

Tədqiqat Quba rayonunun yeməli göbələkləri haqqında ilkin məlumatları əks etdirir. Nümunələr 2017-19-cu illərdə meşə ekosistemindən toplanmışdır. Tədqiqat nəticəsində 14 cinsə aid 17 yeməli göbələk növü (Amanita rubescens, Boletus edulis, B. reticulatus, Cerioporus squamosus, Clitocybe odora, Clitopilus prunulus, Coprinellus micaceus, Hortiboletus rubellus, Laetiporus sulphureus, Leccinellum pseudoscabrum, Legaliana badia, Lycoperdon perlatum, Macrolepiota mastoidea, M. procera, Russula risigallina, R. turci, Xerocomellus chrysenteron) ayırd edilmişdir. Bunlarf dan Legaliana badia Azərbaycan mikobiotası üçün yenidir. Digər bütün növlər tədqiqat ərazisi üçün yenidir. Göbələklərin GPS koordinatları və ekoloji qrupları qeyd edilmişdir.

Açar sözlor: Askomikota, Bazidiomikota, müxtaliflik, ekoloji qruplar, qida keyfiyyati, növ

\section{Новые находки съедобных грибов, собранных в Кубинском районе}

\section{Айтадж А. Алимамадова Дильзара Н. Агаева}

Институт Ботаники НАН Азербайджсана, Бадамдарское шоссе 40, Баку, АZ1004, Азербайджан

Исследование представляет собой первую информацию о съедобных грибах, Кубинского района. Экземпляры собраны в 2017-19 гг. в лесной экосистеме. В результате выявлено 17 видов (Amanita 
rubescens, Boletus edulis, B. reticulatus, Cerioporus squamosus, Clitocybe odora, Clitopilus prunulus, Coprinellus micaceus, Hortiboletus rubellus, Laetiporus sulphureus, Leccinellum pseudoscabrum, Legaliana badia, Lycoperdon perlatum, Macrolepiota mastoidea, M. procera, Russula risigallina, $R$. turci, Xerocomellus chrysenteron) съедобных грибов, относящиеся к 14 родам. Из них Legaliana badia является впервым для микобиоты Азербайджана. Все другие виды явб ляются новым для исследуемого района. Отмечены GPS координаты и экологические группы грибов. Ключевые слова: Аскомицеты, Базидиомицеть, разнообразие, экологические группь, пищевое качество, виды 